\title{
Teachers' Perceptions and Practices of Cooperative Learning and Its Influence on
}

\section{Classroom Learning}

* Ms. Fozia Bashir, M. Phil (Corresponding Author)

** Dr. Muhammad Nisar, Principal

*** Mr. Anar Gul, M.Phil

\begin{abstract}
This study was launched in order to contribute to the body of researchers conducted for investigating teachers' perceptions and practices about cooperative learning in the classroom. The main objective of this study was to learn about the reasons and perceptions of teachers why they choose to implement or not to implement cooperative learning strategies and how the use of the same influences their class classroom teaching and learning the process. The benefits of the cooperative learning strategies are supported by multiple research studies and conclude in students' intellectual performances along with behavioral improvements. Copious research studies focus on the benefits and methods of the cooperative learning process while lacking teachers' perceptions and practices of cooperative learning. Evaluation of teachers' perceptions and practices of cooperative learning in this research study was conducted at the secondary level in district Kohat. The study was descriptive in nature, the questionnaire was developed by the researcher with the kind and immense consultation of the supervisor. The population of the study comprises all the teachers teaching at the Secondary level at district Kohat while 50 teachers were selected using convenient sampling techniques. Keeping in view the cultural restriction only female teachers were taken as the sample of the study. Data were analyzed using descriptive statistics and central tendencies. Analysis of the quantitative questionnaire showed that most of the teachers like and tend to use cooperative learning strategies. The use of these strategies makes their classes not only conducive to learning and but also develops social skills, selfesteem, cooperation and confidence in students.
\end{abstract}

Keywords: Cooperative Learning, Perception, Practices, Classroom Learning Introduction

For our entire lives, we have relationships with others inside our environmental factors to have the option to get understanding (Agarwal and Nagar, 2011; Johnson and Johnson, 1999a; Lerner and Ciervo, 2004). Lerner and Ciervo (2004) strengthened that the ability to talk, expect, and to advantage, every self-assurance and affirmation has vanquished this exchange. The ones dependably planned endeavours and contacts with others round us in like way can be utilized to show kids clear favors foreseen that would take an enthusiasm with others (Lerner and Ciervo, 2004). be that as it may, while youngsters start school, every day association with others round them and their positive conditions are as frequently as possible disregarded endeavouring to help school understudies completely advantage from reliably practices set up in the examination room (Johnson and Johnson, 1999a). For instance, Johnson and Johnson (1975) combat that amidst different address classroom, young people are as frequently as conceivable masterminded in segments and anticipated to take a seat watchfully as paying little heed to the route that to exist as clear novices, taking in content surface presented by strategies for system for the instructor.

According to Zakaria and Zanagon (2007), this address based, instructor focused on planning approach gives understudies just two or three chances to welcome demand or "exchange mind with particular understudies in the class", consequently growing a getting the chance to be acquainted with enjoy wherein they wind up fundamental uninvolved beneficiaries of substances. What students take a

* Department of Education and Psychology, Kohat University of Science and Technology, Kohat Email: farsomal@yahoo.com

** Model High School, Shakardarra, Kohat Email: nisarkust74@ gmail.com

*** Department of Education and Psychology, Kohat University of Science and Technology, Kohat Email: agu19291@gmail.com 
gander at relies on no longer just on the substance material this is taught, yet what's more on the system for school room structure picked by the usage of the mentor (Cole, 2008; Shinn et al., 2003). In truth, Cole (2008) said that once correct guideline, or that which is "attractive, related, diverse, and interesting to a scattering of modalities and winding up more familiar with styles" may be consolidated with practice arranging, the wants of all understudies may be met. This correct insightful conviction needs that careful exercise influencing courses of action and thought to be paid to the techniques chosen for demonstrating content material in the location classroom.

In 21st century address classroom, it isn't unordinary for instructors to go over understudies with a decent measured kind of private examinations, becoming acquainted with capacities, and favoured picking up information of styles. With the goal that you can enhance examining in this watch room environment, a mentor may also put into impact methods that suit the scholastic needs of each infant in the school room. As proposed by Johnson and Johnson (1999a, 1975), those breaking down varieties nearly guarantee that an understudy can be given not very many chances to delight in the non-open collaborations with the coach which may be needed for him or her to unmistakably gravitate toward the thoughts and necessities being outfitted. in any case, teachers can make picking up learning of conditions that expand upon the manner by which college undergrads thinks about from each other through allowing open doors for school children to work of art together for rich exchange, interaction, coordinated effort, and associate input. Indeed, Slavin (1991a) said that "being on a gathering, working for a helpful goal, can be one of the most extreme fascinating exploration in presence".

Policymakers, who've arranged into area state-ordered attempting out, have asked for that specialists in teachers' classroom demonstrate each year the impact in instructional accomplishment (U.S. branch of getting ready, 2010). Instructors must work to gain increase at the comparable time as meeting the wants of a different understudy masses (Hargreaves, 2003; Jackson, 2004). So, as to accomplish informative impact for understudies in of late's school classroom, a lot of research-based completely preparing systems were progressed as fruitful. Instructors have anticipated that would expand their contraption educate of techniques to gather the distinctive desires of understudies that they go up against each single day. convincing teachers go about as look at room facilitators. They use fitting sources and give ending up more familiar with conditions which will make surroundings wherein all youths can watch. they may be in music with the targets of every specialist and see the best approach to cadence lessons to give extensive canvases that successfully attracts understudies.

\section{Purpose of the Study}

The rationale of this watch progress is toward becoming to think about states of mind and impression of the Secondary teachers about agreeable contemplating. The discoveries of this investigate may likewise in addition extend the know-how and the outcome of the usage of agreeable picking up learning of structures inside the region Kohat.

\section{Significance of the Study}

This take a gander at researched teacher's recognitions with respect to agreeable picking up information of structures. The examination outfitted basic records roughly the execution of agreeable picking up information of. A decent method to help undergrads become and remain a hit inside the substance regions, instructors who utilize agreeable breaking down frameworks may also help understudies through offering them with conceivable outcomes to inquire about in a domain that is invigorating and nonthreatening. through concentrating on assessing the usage of helpful learning structures in a particular scholastic environment, this observe provided an exceptional mentality from the current writing praising researcher satisfaction.

\section{Review of Literature}

One instruction approach that has been actualized to meet nowadays' wants is helpful picking up learning of (Slavin, 2010). Agreeable acing has severa points of interest to college understudies which have been pleasantly sure in writing and research-tried for a few quite a while. As expressed by means of the use of Kagan and Kagan (2009), agreeable becoming more acquainted with sports exercises offer a reason for think about room preparing that has the ability to blast best exchange among undergrads and allow them to discover and cooperate in becoming more acquainted with. 


\section{Cooperative Learning}

Cooperative learning sports draw in understudies in obligations in which they might have the capacity to legitimately prepare their associates, and has been built up to bring about more noteworthy maintenance of gave content texture than tuning in without anyone else (Dat Tran, 2013). it's been guaranteed (DePorter, Reardon, and Singer-Nourie, 1998; Metcalf, 1997) that understudies safeguard in contemplations ninety $\%$ of what they prepare others however charming $20 \%$ of what they focus. predictable with Webb (1982), it's been watched always that researchers who watch and keep up the vast majority of the substance material provided in the school room are the individuals who offer and procure exact factors on the situation matter assortment they might become more acquainted with and approaches that they use at the best approach to explore it. while school understudies' artistic creations without anyone else's input, they may now not have the chance to welcome inquiries of companions or participate in profound dispatch about their work. while working agreeably, Agarwal and Nagar (2011) expressed that researchers are engaged to take commitment for his or her own private perusing while at the same time achieving and sharing advancement toward the accomplishment of a considering point with others.

Instructors have utilized helpful contemplating systems in school classroom all through the $u$. s. as they coordinate and situated into affect works on concerning organizations of college understudies running together. Helpful becoming more acquainted with viability inside the classroom to get broad instructional results is very much introduced (Johnson and Johnson, 1999a, 1999b; Johnson, Johnson, and Stanne, 2000; Marzano, Pickering, and Pollock, 2001).

Concerning Johnson, Johnson, and Stanne (2000), the examinations inside the back of pleasing scrutinizing suggests that it is an extraordinary getting ready system, and this is approved with the guide of an abundance of correct examinations including its suitability inside the watch room. As said in analyzes achieved with the benefit of Johnson, Maruyama, Johnson, Nelson, and Skon (1981), Johnson (1981), and Johnson, Johnson, and Smith (1998, 2007), individuals allowed to outlines in an accommodating gathering achieve favoured achievement levels over individuals that are best overseen intense and individualistic learning systems. dependable with Johnson, Johnson, and Holubec (1994a), considers at pleasant, engaged and personal thinking about started in 1898 and contemplating reality that that time, various exploratory and correlational examinations have happened. They continuous by pointing out that those investigation show that pleasing getting data of completions in higher understudy fulfilment, common associations among school students, and higher no matter how you look at its mental prosperity. unravelling the ones outcomes, Johnson et al. (1994a) admonished that "the capable outcomes that interest has on such different fundamental results segregate supportive grabbing taking in of from specific instructional procedures and make it one of the best basic contraptions for ensuring scientist fulfilment".

Sharan (2010) characterized helpful acing as bendy and exhaustive; it consolidates the fantasies of social mix and instructive request. From Sharan's viewpoint, in the meantime as it's far fundamental for all understudies to build a non-open feeling of having a place in an investigate room, for socially separated school undergrads it is basic. past to Sharan's compositions, in advance with Johnson (1981), a more possibility issue is noted for youngsters who're socially remoted and pulled back from companions and are at a higher risk for a determination of modification issues as they age. ensuing to this work, Lew, Mesch, Johnson, and Johnson (1986) suggested that mediations are basic in classroom a marvellous method to convey understudies the likelihood to advantage position in get admission to degree conditions in which powerful communications and individual connections can increment. Helpful circumstances would in truth enable children to look at and given the chance to utilize relational and little organization abilities.

The essential objectives of agreeable becoming more acquainted with are to urge understudies to collaborate in exercises that are scholastically more entangled than the ones they can get admission to beneath conventional address procedures, subsequently picking up inspiration to perform at larger amounts because of full of feeling and social inclusion inside the exercise (Sharan, Hertz-Lazarowitz, and Ackerman, 1980). Accordingly, helpful considering supplements the mentor's planning by way of giving undergrads the likelihood to fine art together to set their insight into the objectives which can be being educated in an address room. the desire is that by means of teaming up in agreeable learning sports, each the understudies' social and scholarly abilities are diffused. 


\section{Theoretical Framework}

Never again like other educating and acing techniques, the purpose of joining of pleasant getting to be familiar with is the vivacious duty of understudies inside the acing structure and the planned exertion anticipated that would play out a given mission. in wander with Johnson and Johnson $(1975,1989)$, Johnson, Johnson, and Holubec (1991, 1994a, 1994b), Kagan (1994), Kagan and Kagan (2009) and Slavin (1990) pleasing considering is locked in round the academic use of little relationship of understudies cooperating to expand their own stand-out and every interesting's grabbing data of. understudies are doled out to associations with the guide of the instructor to lead a run of the mill method of reasoning.

Kagan (1994) and Kagan and Kagan (2009) struggled that there are four basic parts expected to reasonably increment honest to goodness pleasing winding up more familiar with cases:

Positive interdependence

Individual accountability

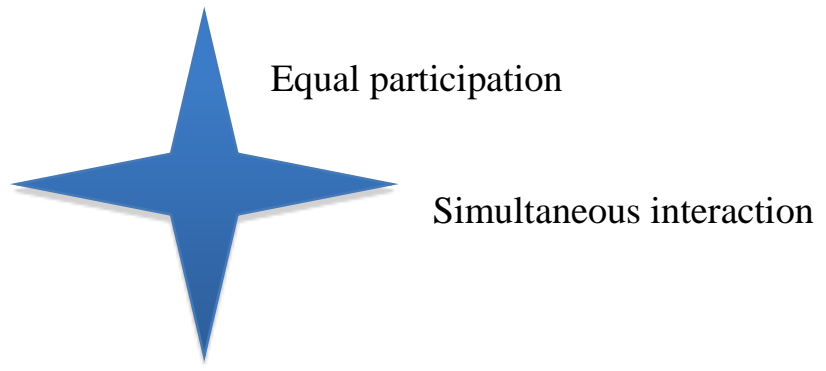

Figure 1: Four Elements of Effective Cooperative learning

The motivation behind every researcher association is to rate insights and man or lady points of view at the relegated test to have the capacity to create a completed item through the utilization of measurements got from all team people. Johnson, Johnson, and Smith (1998) recommended that previous to 1970, pleasant considering research concentrated on school understudies. Regardless, okay 12 educators got excitement inside the school room strategy and started compelling in their address classroom in the mid Nineteen Seventies. the utilization of supportive acing strategies inside the classroom is grounded in the theories of constructivism, social looking at thought, and social dependence.

\section{Cooperative learning in classroom}

"Human beings are social creatures by strategy for technique for nature and support has been used inside the course of records in all parts of our lives. in this manner, it takes after that accommodating getting to be familiar with associations in assets could be used as a sensible training approach" (Dewey, 2001). Accommodating inspecting is a standout amongst the most extraordinary unlimited areas of studies, lead, and exercise utilized as a part of classroom (Johnson, Johnson, and Stanne, 2000; Kagan, 1994; Kagan and Kagan, 2009; Slavin, 1991b). concerning Kagan and Kagan (2009), pleasing mulling over isn't for the most part truly an unmarried analyzing technique, yet as a substitute a course of action of take a gander at room strategies in which a fundamental a bit of the inspecting way is produced using understudy participation that is based on goals and curricular surface.

Regardless of reality that pleasing getting learning of is used as a showing strategy in twenty first century school classroom, is unquestionably not a fresh out of the box new thought and might be taken after as far returned as John Dewey (Lambert et al., 2002). at the flip of the twentieth century, Dewey encouraged instructors to have school understudies' wonderful signs everything considered in acing clusters remembering the ultimate objective to research and cure issues through the method of encouraged effort (Ellis and Whalen, 1990). Dewey, as bare essential by techniques for Lambert et al., make to be an affect for a coaching that secured chances to experience right and vital commitments and for address classroom wherein attempts of understudies worked together to amass their getting information of examinations. This arranging strategy can be settled in 21 st century classroom through frameworks of steady investigating wherein understudies are permitted to diamond aggregately so as to advantage new data and learning by technique for sharing their blended and character discernments and evaluates (Lambert et al., 2002). 


\section{Advantages of Cooperative Learning}

While scanning for instructive systems to use in the investigation space for the reason of creating understudy examining, a coach needs to mindfulness on the examinations that can be accomplished on the picked scholarly strategy. with regards to Willms (2002), "agreeable considering has been comprehensively inquired about and used in address classroom round the world for the thought process that Seventies". The classroom points of interest of this training system are various. "Helpful examining has been advised as the answer for an incredible cluster of instructional issues" (Slavin, 1995). A union of concentrates on agreeable learning approved that the ones procedures had been seen to build the scholastic accomplishment of school understudies, help enhancing relational gifts among various organizations, enhance emotional well-being, help in growing a greater quality researcher considerations set towards becoming more acquainted with, and help to get ready understudies for the predetermination fine art weight.

\section{Achievement}

One of the most extreme basic advantages connected to the execution of helpful acing is enhanced understudy accomplishment (Johnson and Johnson, 1983, 1985, 1990, Johnson, Johnson, and Stanne, 2000; Kagan and Kagan, 2009; Lazarowitz and Kersenty, 1990; Mesch, Johnson, and Johnson, 1987; Panitz, 1999; Slavin 1995). "instructional endowments incorporate advancing basic pondering abilties, identified with understudies effectively inside the becoming more acquainted with strategy, upgrading school room impacts, demonstrating appropriate student inconvenience settling methods, customizing huge addresses and persuading college undergrads in particular educational program" (Panitz, 1999).

The development and increment in instructive satisfaction are supported through various meta-examinations. inside the investigation of 122 research construct for the most part in light of organization work from 1924 to 1981, understudies teaming up in a helpful perusing condition for the most part had higher instructive accomplishment than their contrary numbers never again running with examine room pals (Johnson and Johnson, 1983). This equivalent stop result progress toward becoming copied by method for Johnson and Johnson (1990) of their later research of 323 investigations. Slavin (1995) additionally agreed with this result on instructional accomplishment. Slavin found that amid sixty-seven research focused at the accomplishment results of forcing helpful learning strategies in address classroom at the basic and auxiliary stages, $61.0 \%$ (forty-one) of the examination chose broadly better accomplishment in agreeably, understudy centered showed control bunches than in generally, mentor centered educated oversee organizations. those impacts had been estimated using the utilization of indistinguishable wants connected in all directions and the results that have been created while college understudies were surveyed on these objectives. high top of the line results had been accomplished inside the center points of math, English dialect expressions, breaking down, and social examinations, and had been expressed over the span of all review levels, in urban, rustic and rural schools and for all achievement ranges (low, medium. what's more, extreme; Slavin, 1995).

In a meta-examination of 158 research, Johnson, Johnson, and Stanne (2000) without question that surveys come about proposed affirmation on the utilization of pleasing learning techniques and their ability to make magnificent accomplishment comes about. The examinations in the metaexaminations included 8 approaches of pleasing grabbing data of: acing with everything taken into account and alone, gainful Controversy, Jigsaw, understudy packs achievement Divisions (STAD), group expanded getting ready (TAI), Cooperative included scrutinizing and Composition (CIRC), workplaces entertainments Tournaments (TGT) and affiliation considers. In each watch, paying little mind to the technique used, the accomplishment levels had been surprisingly better meanwhile as pleasing looking at strategies have been realized meanwhile as conversely with individualistic or centered frameworks of getting data of.

Also, ponders through Mesch, Johnson, and Johnson (1987) asserted that learning obtained accommodatingly drawn out fulfilment gets. For this test, associations of tenth grade understudies had been checked for a half year. One foundation shared in bearings that finished pleasing mulling over techniques, while the elective affiliation come to be instructed the use of individualized training. the understudies who took part in helpful learning partnerships improved an astounding arrangement appraisal at the tests given to the two organizations. never again best did the scientists be cognizant profit in instructional satisfaction, they additionally found that no terrible outcomes have been put 
with the use of heterogeneous gatherings in expressions of accomplishment degrees, race, and sexual orientation. accordingly, the analyze not handiest showed the idea that execution of helpful acing may likewise need to improve accomplishment; it additionally upheld the use of consolidated, heterogeneous gathering of understudies.

Advanced fulfilment expands as a result of the utilization of pleasant acing systems had been investigated and checked all through understudy age ranges, limit stages, consider room subjects, and moved obligations (Johnson and Johnson, 1983; Kagan and Kagan, 2009; Lazarowitz and Karsenty, 1990). school understudies allowed to finish duties on a pleasant scrutinizing bunch scored higher than their contrary numbers in science significance (Lazarowitz and Karsenty, 1990). Johnson and Johnson (1985) picked that in the midst of 21 of 26 analyze build totally regarding understudies from different level stages, mulling over capacities, sex, and race, all the more insightful accomplishment adjusted into communicated for school students working in supportive scrutinizing affiliations.

\section{Disadvantages of Cooperative Learning}

While emerge helpful becoming acquainted with methods are performed inside the observe room. those favors can frequently dominate some of the demonstrated shortcomings which could go with this preparation strategy (Randall, 1999). issues that have been recorded even as actualizing agreeable perusing systems that could be gone up against through educators and undergrads envelop: additional making arrangements time for educators, instructor vulnerabilities of overlaying all the required substance fabric and models due to the delayed classroom time expected to execute the helpful examining sports, deficient master advancement required to proficiently educate the coach to put into affect the helpful procedures as justified by utilizing the investigations, and absence of researcher social gifts wished to take an interest as an effective organization part. (Zakaria and Zanagon, 2007). also, private wanted instructing styles routinely affect an instructors' utilization or loss of utilization of any training strategy (Grasha, 2002). those requesting circumstances can keep the expense and satisfaction of the execution of helpful picking up information of as a training approach. They can likewise modify the way wherein agreeable acing is utilized inside the address room, and maybe create invalid results with thinks about. As expressed by utilizing way of Siegel (2005), "If educators likely change agreeable becoming acquainted with as they execute it, the aftereffects of semi trial investigations of helpful considering could have bound generalizability to genuine presence address classroom". Special standards exist among teachers and analysts while tending to the trading of agreeable dissecting models for use in the take a gander at room. while analysts perceive change of research-based absolutely systems as unpleasant execution, educators comprehend the progressions as current inconvenience unravelling that is required to satisfy the necessities of all undergrads inside the address room (Cuban, 1996).

\section{Methodology}

Numerous studies on cooperative learning utilizing subjective philosophy have looked into numerous angles including instructors and their usage of agreeable learning in the study hall (Ames and Ames, 1984; Ross, 1994; Siegel, 2005). These subjective investigations investigated the mentalities, inspirations, and sentiments of instructors concerning agreeable learning, and reported data from the educator's point of view. This examination, notwithstanding, was expressive in nature. The main purpose of this study was to investigate the perception, attitude of the teachers about the cooperative learning and how the use of these practices helps them in improving the classroom learning of the students.

\section{Population of the Study}

All the Secondary school teachers working in district Kohat form the population of the study.

\section{Sample of the Study}

A sample is small portion of population of the study. The sample size was selected as eight schools representing the whole population. The school was randomly selected from the population. Using the convenient sampling technique only Secondary School teachers were selected as the sample of the study.

\section{Research instrument}

Data from the field was collected through questionnaires. The researcher administered the questionnaires personally A questionnaire using 5-point likert scale was developed keeping the consultation of the supervisor. 


\section{Data Analysis}

Data collected through questionnaires was tabulated, analyzed and interpreted by using frequency and percentage methods. Data was analyzed using descriptive statistics and central tendencies. Some workable recommendations were made to improve the situation.

\section{Results and Discussions}

In this area the procedure of information investigation and the outcomes accomplished are introduced. As referenced in past segments, the information gathered for this examination was accumulated through the conveyance of a poll among 50 Secondary School teachers the information examination of the per proclamation is clarify here quickly:

Table: 1 Responses of Teachers perceptions Regarding Cooperative Learning - I

\begin{tabular}{|c|c|c|}
\hline Item No. & Item Statement & Item Responses \\
\hline Item 1 & $\begin{array}{l}\text { I understand cooperative learning } \\
\text { well enough to implement it } \\
\text { successfully. }\end{array}$ & $\begin{array}{l}\text { Most of the teachers are of the view that they better } \\
\text { understand cooperative learning }\end{array}$ \\
\hline Item 2 & $\begin{array}{l}\text { Competition best prepares } \\
\text { students for the real world. }\end{array}$ & $\begin{array}{l}\text { As cooperative teaching is very much effective and it } \\
\text { demands students involvement so it indirectly prepare } \\
\text { them to face the real-life problems. }\end{array}$ \\
\hline Item 3 & $\begin{array}{l}\text { For me to succeed in using } \\
\text { cooperative learning depends on } \\
\text { receiving support from me } \\
\text { colleagues. }\end{array}$ & $\begin{array}{l}\text { Cooperation is one of the major keys of cooperative } \\
\text { learning. But fifty percent respondent said that they } \\
\text { don't get any support from their colleagues while the } \\
\text { other said that they help each other and it bears great } \\
\text { fruit for all of them. }\end{array}$ \\
\hline Item 4 & $\begin{array}{l}\text { Using cooperative learning } \\
\text { enhances my career advancement }\end{array}$ & $\begin{array}{l}\text { Most of the teachers express their view that cooperative } \\
\text { learning enhanced their teaching skills }\end{array}$ \\
\hline Item 5 & $\begin{array}{l}\text { I have too little teaching } \\
\text { experience to implement } \\
\text { cooperative learning successfully. }\end{array}$ & $\begin{array}{l}\text { The successful implementation of the cooperative } \\
\text { learning needs great experience and efforts on the part } \\
\text { of the teachers as it is totally different from the } \\
\text { traditional teaching learning method }\end{array}$ \\
\hline Item 6 & $\begin{array}{l}\text { Engaging in cooperative learning } \\
\text { enhances students' social skills. }\end{array}$ & $\begin{array}{l}\text { Cooperative learning is an essential tool in developing } \\
\text { the social skills among the students. }\end{array}$ \\
\hline
\end{tabular}

Table: 2 Responses of Teachers perceptions Regarding Cooperative Learning - II

\begin{tabular}{lll}
\hline Item No. & & Item Statement \\
\cline { 1 - 1 } $\begin{array}{ll}\text { Item } 7 & \text { students are resistant to } \\
\text { working in cooperative groups. }\end{array}$
\end{tabular}

Item 8 Cooperative learning helps meet my school's goals.

Item 9 Using cooperative learning fosters positive student attitudes towards learning.

Item 10 I find that cooperative learning is too difficult to implement successfully.

Item 11 If I use cooperative learning, my classroom is too noisy.

Item 12 The physical set-up of my classroom is an obstacle to using cooperative learning.

\section{Item Responses}

Research studies shows that students show reluctance in participating such activities which require active involvement on their part.

Cooperative learning is a powerful tool that can help in the successful achievement of school's goal.

Research findings show that cooperative learning develops a positive attitude among the learners.

Sometimes it becomes difficult for the teachers to implement Cooperative learning strategies because students show reluctance or sometimes, they have lack of resources.

One of the most important requirements of the cooperative learning is flexibility in the discipline of the class. So, most of the teachers complain that they don't get any support from the administrative of the school.

Research conclusions reveal the fact that most of the physical set up of the classroom is not suitable in using cooperative learning.

\section{Frequency}

Frequency of the research questions (Item 7 to Item 12) is disquessed below which shows the significance of applying cooperative learning and how it improves the classroom learning of the learners. 


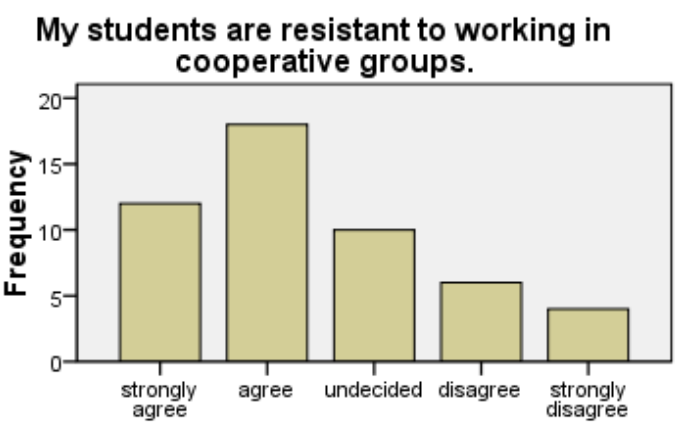

My students are resistant to working $\mathrm{i}$...

Using cooperative learning fosters positive

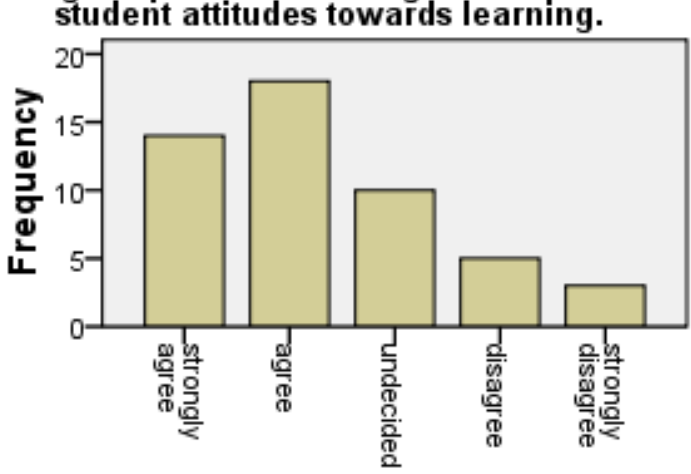

If I use cooperative learning, my classroom is too noisy.

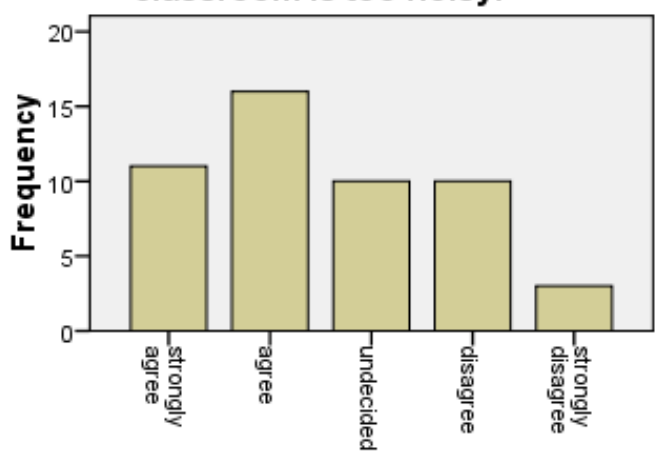

If I use coonerative learnina. mv

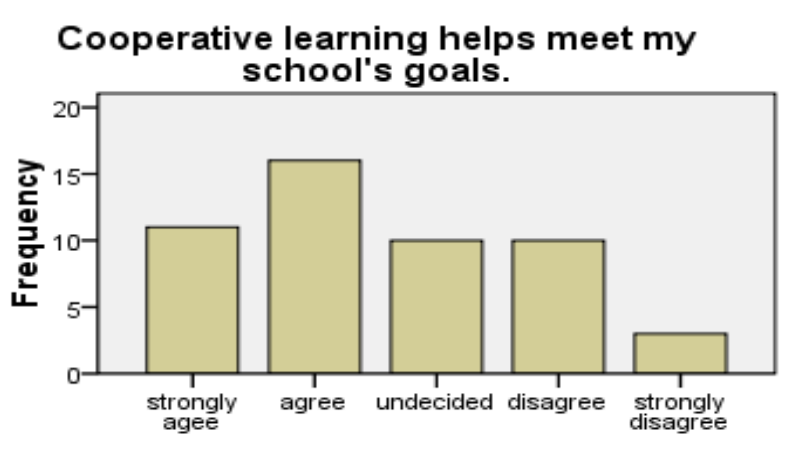

Cooperative learning helps meet my ...

I find that cooperative learning is too difficult to implement successfully.

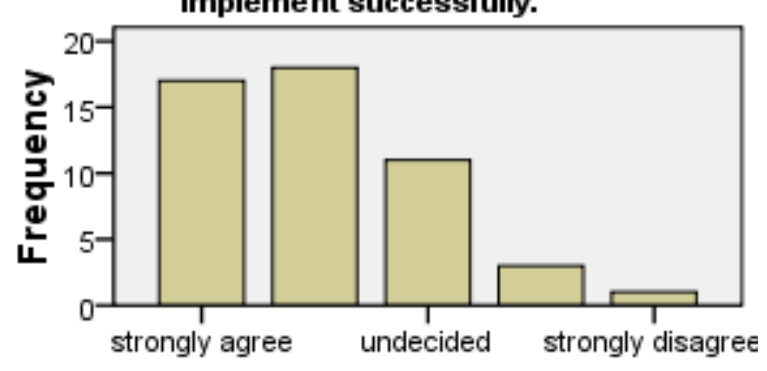

I find that cooperative learnin...

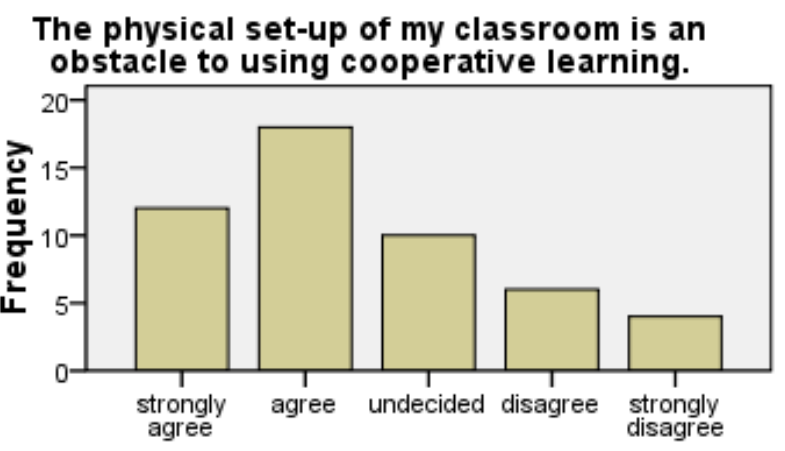

The physical set-up of my classroom i...

\section{Conclusions and Discussion}

The results of this study showed the members hold for the most part a positive perspective of the execution of helpful methodologies in instructing and learning setting. This is most likely on the grounds that when understudies work in bunches, they feel that they can rely upon others for help and this gives them the certainty to take care of issues and appreciate learning. Uplifting state of mind towards agreeable methodologies may in a roundabout way change the students' demeanour towards dialect learning and energize their advantage.

In light of discoveries of the examination, it is important that educators utilize helpful learning approach one next to the other with non-agreeable learning approaches. It merits specifying that effective usage of agreeable learning strategies requires fundamentally arranged educating and learning exercises. Likewise, it is prescribed that this approach be utilized for abilities like perusing cognizance since helpful taking in gathers proposals and thoughts from various gathering individuals and contributes the ideas turn out to be effortlessly clear. Besides, this approach can likewise be utilized for the guideline in different abilities, for example, tuning in, talking, and composing. What's more, the writing recommends that extra reasons may rouse the educators to utilize agreeable learning strategies. For example, "the capacity to work with others inside a gathering and to create relational 
aptitudes" may be a worthy defense for executing helpful learning procedures (Abu and Flowers, 1997).

\section{References}

Agarwal, R., \& Nagar, N. (2011). Cooperative learning. Delhi, India: Kalpaz.

Allen, E. E. (1995). Active learning and teaching: Improving postsecondary library instruction. The Reference Librarian, 24(51-52), 89-103. doi: 10.1300/J120v24n51_10

Ames, A., \& Ames, R. (1984). Systems of student and teacher motivation: Toward a qualitative definition. Journal of Educational Psychology, 76(4), 535-556.

American Association of Colleges of Teacher Education and the Partnership for 21st Century Skills. (2010). 21st century knowledge and skill in education preparation [White paper]. Retrieved from: http://www.p21.org/storage/documents/aacte_p21_whitepaper2010.pdf.

Bonwell, C. C., \& Eison, J. A. (1991). Active learning: Creating excitement in the classroom. ASHEERIC Higher Education Report No. 1. Washington, DC: The George Washington University, School of Education and Human Development.

Boudourides, M. A. (1998, July). Constructivism and education: A shopper's guide. Paper presented at the International Conference on the Teaching of Mathematics, Samos, Greece.

Bromley, K. \& Modlo, M. (1997). Using cooperative learning to improve reading and writing in language arts. Reading and Writing Quarterly, 13(1), 21-35.

Brooks, J. G., \& Brooks, M. G. (1999). In search of understanding: The case for constructivist classrooms. Alexandria, VA: Association for Supervision and Curriculum Development.

Candler, L, (1995). Cooperative learning and wee science. San Juan Capistrano, CA: Kagan Cooperative Learning.

Candler, L. (n.d). Quiet signals and timers. Retrieved from http://www.lauracandler.com/ strategies/quiet.php

Caposey. T. \& Heider, B. (2003). Improving reading comprehension through cooperative learning (Master's thesis). Retrieved from ERIC. (ED 478 463).

Cole, R. W. (2008, June). Educating everybody's children: Diverse teaching strategies for diverse learners (revised and expanded 2nd ed.). Alexandria, VA: Association for Supervision and Curriculum Development. P.1

Costa, A. L., \& Kallick, B. (2004). Assessment strategies for self-directed learning. Thousand Oaks, CA: Corwin.

Creswell, J. W. (2012). Educational research: Planning, conducting, and evaluating quantitative and qualitative research (4th ed.). Boston, MA: Pearson.

Curry, P., De Amicis, L., \& Gilligan, R. (2011). The effect of cooperative learning on interethnic relations in schools. Society for Research on Educational Effectiveness. Retrievedfrom http://files.eric.ed.gov/fulltext/ED519148.pdf

Cziprok, C. D., \& Popescu, F. F. (2015). Project based learning upon the constructivist method for high school physics lessons.

Davoudi, A. H. M., \& Mahinpo, B. (2012). Kagan cooperative learning model: The bridge to foreign language learning in the third millennium. Theory and Practice in Language Studies, 2(6), 1134-1140. doi: 10.4304/tpls.2.6.1134-1140

Day, S. P., \& Bryce, T. G. K. (2013). The benefits of cooperative learning to socioscientific discussion in secondary school science. International Journal of Science Education, 35(9), 1533. http://dx.doi.org/10.1080/09500693.2011.642324

Dewey, J. (1938). Experience and education. New York, NY: Macmillan. P 1.

Diego, D. (2013). Teacher preparation, professional development, and long-term English learners. International Journal of Education, 5(4), 1-17.

Edwards, S. (2015). Active learning in the middle grade's classroom: Overcoming the barriers to implementation. Middle Grades Research Journal, 10(1), 65-81. Retrieved from https://www.questia.com/library/journal/1P3-3726276411/active-learning-in-themiddlegrades-classroom-overcoming

Eskay, M., Onu, C. V., Obiyo, N., \& Obidoa, M. (2012). Use of peer tutoring, cooperative learning, and collaborative learning: Implications for reducing anti-social behavior of schooling adolescents, 932-945. Retrieved from http://files.eric.ed.gov/fulltext/ED538819.pdf Facing 
history and ourselves. (2017, March 1). Retrieved from https://www.facinghistory.org/ resource-library/teaching-strategies/give-one-get-one.

Ferguson-Patrick, K. (2012). Developing an inclusive democratic classroom "in action" through cooperative learning. Australian Association for Research in Education. Retrieved from http://files.eric.ed.gov/fulltext/ED542298.pdf

Fernandez-Rio, J. (2015). Models-based practice reloaded: Connecting cooperative learning and adventure education. Journal of Physical Education, Recreation \& Dance, 86(6), 5-7. http://dx.doi.org/10.1080/07303084.2015.1054197

Foss, E., Guha, M. L., Papadatos, P., Clegg, T., Yip, J., \& Walsh, G. (2013). Cooperative inquiry extended: Creating technology with middle school students with learning differences. Journal of Special Education Technology, 28(3), 33. https://doi.org/10.1177/016264341302800303

Gagné, N., \& Parks, S. (2013). Cooperative learning tasks in a grade 6 intensive ESL class: Role of scaffolding. Language Teaching Research, 17(2), 188-209. http://dx.doi.org.cupdx.idm. oclc.org/10.1177/1362168812460818

Goldenberg, C. (2013). Unlocking the research on English learners: What we know and don't yet know. American Educator, 37(38), 4-11.

Grabe, W., \& Stoller, F. L. (2011) Teaching and researching reading (2nd ed.) New York, NY: Pearson Education.

Groccia, S. W. (2014). The cooperative learning model in middle school physical education. Research Quarterly for Exercise and Sport, 85, 1.

Han, M. (2015). An empirical study on the application of cooperative learning to English listening classes. English Language Teaching, 8(3), 177-184. doi:10.5539/elt. v8n3p177

Hattie, J. (2003). Teaching in the Knowledge Society. Maidenhead: Open University Press.

Honigsfeld, A., \& Dove, M. G. (2012). Collaborative practices to support all students. Principal Leadership, 12(6), 40-44. Retrieved from http://coteachingforells.weebly.com/uploads/8/0/ 6/6/8066516/collaborative_practices_to_support_all_studentss.pdf

Horton, L. (1990). Cooperative learning in English. English Journal, 79(6), 74-77.

Hosseni, S. M. H. (2012). Beyond the present methods and approaches to eld/education: The crucial need for a radical reform. Tehran: Jungle Publications.

Hsiung, C. M., Luo, L. F., \& Chung, H. C. (2014). Early identification of ineffective cooperative learning teams. Journal of Computer Assisted Learning 30(6), 534-545.

Hsiung, C. M., Luo, L. F., Lin, C., \& Wang, P. (2014). Identification of dysfunctional; cooperative learning teams and troubled individuals. British Journal of Educational technology 45(1), $125-135$.

Irvine, J. J. (1999). The education of children whose nightmares come both day and night. The Journal of Negro Education, 68, 244-254.

Jigsaw classroom. (2017, March 1). Retrieved from https://www.jigsaw.org/.

Johnson, D. W., \& Johnson, R. T. (1989). Cooperation and competition: Theory and research. M. N: Interaction Book Company Edna.

Johnson, D. W., \& Johnson, R. T. (1994). Learning together and alone: Cooperative, competitive and individualistic learning. Boston, MA: Allyn and Bacon.

Johnson, D. W., \& Johnson, R., \& Holubec, E. (1990). Circles of learning: cooperation in the classroom. Alexandria, VA: Association for Supervision and Curriculum Development.P12.

Johnson, D. W., \& Johnson, R., \& Smith, K. (2000). Constructive Controversy: The educative power of intellectual conflict, Change, 32(1), 28-38.

Kharaghani, N. (2015). The impact of vocabulary knowledge on reading comprehension ability of Iranian English learners receiving reciprocal teaching and cooperative grouping intervention program. International Journal of Research Studies in Education, 4(3), 47-56.

King, A., Stafferi, A., \& Adelgais, A. (1998) Mutual peer tutoring: Effects of struggling tutorial interaction to scaffold peer learning. Journal of Educational Psychology, 9(1), 134-152.

Komiyama, R. (2013). Factors underlying second language reading motivation of adult EAP students. Reading in a Foreign Language, 25(2), 149-169.

Kunsch, C., Jitendra, A., \& Sood, S (2007). The effects of peer mediated instruction in mathematics for students with learning problems: A research synthesis. Learning Disabilities Research and Practice, 22(1), 1-12. 
Ladson-Billings, G. (1995). Toward a theory of culturally relevant pedagogy. American Educational Research Journal, 32, 465-491.

Lau, P., Kwong, T., King, C., \& Wong, E. (2014). Developing students' teamwork skills in a cooperative learning project. International Journal for Lesson and Learning Studies, 3(1), 8099. doi: 10.1108/IJLLS-03-2013-0018

Luo, Y., Sun, Y., \& Strobel, J. (2013). The effects of collectivism-individualism on the cooperative learning of motor skill. Journal of International Students, 3(1), 41-51. Retrieved from http://files.eric.ed.gov/fulltext/EJ1056443.pdf

Lv, Y. (2014). Cooperative learning: An effective approach to college English learning. Theory and Practice in Language Studies, 4(9), 1948-1953. doi: 10.4304/tpls.4.9.1948- 1953

Martinez, R., S., Harris, B., \& McClain, m. b. (2014). Practices that promote English reading for English learners. Journal of Educational \& Psychological Consultation, 24(2), 128. http://dx.doi.org/10.1080/10474412.2014.903192

Merriam, S. B. (1998). Qualitative research and case study applications in education ( $2^{\text {nd }}$ ed.). San Francisco, CA: Jossey-Bass.

Mitakidou, S., \& Tamoutseli, K. (2011). Engaging learners in cooperative learning through environmental and cross-cultural activities. Journal of Teacher Education for Sustainability, 13(1), 5-n/a. http://dx.doi.org/10.2478?v10099-011-0001-5

Mohammadjani, F., \& Tonkaboni, F. (2015). A comparison between the effect of cooperative learning teaching method and lecture teaching method on students' learning and satisfaction level. International Education Studies, 8(9), 107-112. doi: 10.5539/ies. v8n9p107

Nan, H. (2014). A feasible study on cooperative learning in large class college English teaching. Theory and Practice in Language Studies, 4(9), 1862-1868. doi: 10.4304/tpls.4.9.1862-1868

Newmann, F., \& Wehlag, G. (1993) Five standards of authentic instruction. Educational Leadership, 50(7), $1-7$.

Oyarzun, B. A., \& Morrison, G. R. (2013). Cooperative learning effects on achievement and community of inquiry in online education. Quarterly Review of Distance Education, 14(4), 181-194, 255.

Piaget, J. (1926). The language and thought of a child. New York, NY: Harcourt, Brace.

Plonsky, L. (2011). The effectiveness of second language strategy instruction: A metaanalysis. Journal of Language Learning, 61(4), 993-1038. doi: 10.1111/j.1467-9922.2011.00663

Purzer, S. (2011). The relationship between team discourse, self-efficacy, and individual achievement: A sequential mixed-methods study. Journal of Engineering Education, 100(4), 655-679.

Puzio, K, \& Colby, G. T. (2013). Cooperative learning and literacy: A meta-analytic review. Journal of Research on Educational Effectiveness, 6(4), 339-360.

Rowe, K. (2003). The importance of teacher quality as a key determinant of students' experiences and outcomes of schooling. Paper presented at the ACER Research Conference, Melbourne.

Sadeghi, M. R. (2012) The effects of cooperative learning on critical thinking in an academic context. Journal of Psychological and Educational Research, 20(2), 15-30.

Retrieved from https://www.questia.com/read/1P3-2872117161/the-effects-of cooperative-learningon-critical-thinking

Salako, E. C., Eze, I. R., \& Adu, E. O. (2013). Effects of cooperative learning on junior secondary school students' knowledge and attitudes to multicultural education concepts in social studies. Education, 133(3), 303-309.

Sanders, W. L., \& Rivers, J. C. (1996). Cumulative and residual effects of teachers on future student academic achievement.

Sears, D. \& Pai, H. (2012). Effects of cooperative versus individual study on learning and motivation after reward-removal. The Journal of Experimental Education, 80(3), 246-262, doi: 10.1080/00220973.2011.602372

Slavin R. (1995) Cooperative learning: Theory, research, and practice (2nd ed.). Boston: Allyn \& Bacon.P.8

Stevens, R. (2003). Student team reading and writing: A cooperative learning approach tomiddle school; literacy instruction. Educational Research and Evaluation, 9, 137-160. 
Stevens, R., \& Slavin, R. (1995). Effects of a cooperative learning approach in reading and writing on academically handicapped and non-handicapped students. The Elementary School Journal, 95(3), 241-263.

Wenzel, T. (2000). Cooperative student activities as learning devices. Retrieved from http://serc.crleton.edu/resources/1615.html

Willms, J. D. (2003). Student engagement at school: A sense of belonging and participation: Results from PISA 2000. Publications de l'OCDE. P.359

Wittrock, M. C. (1978). The cognitive movement in instruction. Educational Psychologist, 13, 15-2.

Yueh-Min, H., Yi-Wen, L., Shu-Hsien Huang, \& Hsin-Chin, C. (2014). A jigsaw-based cooperative learning approach to improve learning outcomes for mobile situated learning. Journal of Educational Technology \& Society, 17(1), 128-140. Retrieved from http://www.ifets.info /journals/17_1/12.pdf

Yuretich, R. F., \& Kanner, L. C. (2015). Examining the effectiveness of team-based learning (TBL) in different classroom settings. Journal of Geoscience Education, 63(2), 147-156. http://dx.doi.org/10.5408/13-109.1

Zainuddin. (2015). The effect of cooperative integrated reading and composition technique on students' reading descriptive text achievement. English Language Teaching, 8(5), 11-21. http://dx.doi.org/10.5539/elt.v8n5p11.35 